\title{
Canva as a Media for Exploration of Indonesian Tourism Knowledge in BIPA Learning
}

\author{
Octo D. Andriyanto ${ }^{1, *}$ Meilita Hardika ${ }^{2}$ Sukarman Sukarman ${ }^{3}$ \\ ${ }^{1,3}$ Universitas Negeri Surabaya, Indonesia \\ ${ }^{2}$ Surabaya European School, Indonesia \\ *Corresponding author. Email : octoandriyanto@unesa.ac.id
}

\begin{abstract}
This article discusses characteristics, cultural and tourism insights, and creativity of BIPA students in 6th-grade elementary school at Surabaya European School through infographics or media Canva. BIPA learning requires creative selection, media usage, and strategies oriented to the learning process. Media Canva is a solution to increase student creativity by combining IT skills and Indonesian insights comprehensively. This research uses qualitative descriptive by applying the project-based learning method. The data results from a project assignment using the Canva application to present Indonesian tourism infographics. The data was collected by observation, field notes, and documentation. This study obtained three main results: (1) the characteristics of Year 7 students at SES have independence in operating IT and good communication skills; the language level is averaged at B1 and B2, (2) tourism and cultural insights at SES are obtained through academic tourism activities, field studies in cultural places, historical tours, and social activities, and (3) student creativity in expressing travel knowledge to Canva media infographics is carried out to hone Indonesian, IT, and student creativity competencies. The use of infographic presentations has the complexity of student competencies regarding grammar, graphic design, and mastery of language skills.
\end{abstract}

Keywords: Media Canva, Exploration of travel knowledge, BIPA.

\section{INTRODUCTION}

Learning Indonesian for Foreign Speakers (BIPA) has a different character from learning Indonesian in general. BIPA learning is not always oriented to language learning but also learning about culture, local wisdom, including tourism in Indonesia. The material regarding Indonesian insights is contained in the Graduate Competency Standards of BIPA Permendikbud No. 27 of 2017 [1]. This material is an essential substance for BIPA students to enrich knowledge about culture and conditions in Indonesia, which is no less important than supporting the Indonesian language learning process for international students.

In the current pandemic era, BIPA learning is carried out online with various platforms, in line with the learning objectives to be achieved. Online learning has advantages and disadvantages for teachers. It does not rule out the possibility of bringing up its own challenges for teachers, both in terms of technical matters and the delivery of learning substance. BIPA students also experience this during the learning process. In ideal learning, teachers and students must be active, responsive, and cooperative. BIPA learning is expected to be carried out in a varied, substantive, and innovative manner according to the needs of students [2]. Students' activeness can be demonstrated through learning strategies that stimulate students to participate actively in class. Student activity can be demonstrated through cultural practices, role-playing, and answering questions related to the Indonesian language theme with the online language page.

There are more BIPA students now. Adult and children's students also seem to show interest in learning BIPA, such as at the Cooperation Education Unit School (SPK) and Surabaya European School (SES). International students studying BIPA start at the Montessori level. BIPA students at SPK are unique since international students come to Indonesia to study at the school starting from different levels, some starting from Montessori, or even studying in Indonesia at the secondary level. This impacts the level of Indonesian language proficiency that they must learn, so it has 
become a normal thing; in one class, there are different levels of BIPA learning.

All DSS in Indonesia can certainly refer to two curricula, namely the international curriculum and the national curriculum. BIPA learning at SPK still refers to the national curriculum up to Year 9 (equivalent to Junior High School grade 8). At the Year 10 and Year 11 levels (Junior High School grade 9 and Senior High School grade 10), BIPA learning already refers to the international curriculum; in this case, SES refers to the Cambridge curriculum. This is because, at this level, children are prepared to take the IGCSE (International General Certificate of Secondary Education) final test BIPA. The application of the Cambridge curriculum aims to make students more love and enjoy the learning process itself, not only results-oriented. This curriculum also focuses on the students' interests and talents so that the students' skills and abilities are more specifically and deeply honed. This is one of the Cambridge curriculum designs that is oriented to explore their knowledge from "what" to "how" to focus on their expertise and skills. This curriculum does not require students to succeed in all subjects offered.

BIPA learning at SES has been running dynamically. Optimizing the learning process based on IT, mainly software education, is inseparable from online BIPA learning. For example, to study tourism in Indonesia, a particular strategy is needed to explore and find various existing information by utilizing various media. Not only that, students then pour their knowledge and insight into culture and tourism through infographics using Canva media. Learning Indonesian cultural knowledge is not enough just to use audiovisual media. It also requires students to find information independently and recast their ideas according to the understanding obtained through the reading process from various sources.

Exploration of tourism knowledge in BIPA learning through Canva media presents a different challenge. In addition to the substance and content included in the media, students have also faced challenges related to the students' skills in designing the material presented. Cognitive skills and aspects of learner skills will be integrated through the use of Canva media. The output of using Canva media can be used to explore students' Indonesian language skills. Students can take advantage of the media created to be used as presentation media, which can certainly stimulate speaking skills and other language skills. This media provides an opportunity for students to explore basic literacy knowledge and digital literacy in accordance with current developments.

The focus of this article describes the characteristics, cultural and tourism insights, as well as the creativity of BIPA students at the Surabaya European School in expressing ideas about tourism to Canva infographics or media. It is hoped that this paper will become an alternative for teachers to introduce the language and Indonesian culture in a modern, engaging and applicable way.

\section{METHODS}

This article is a qualitative descriptive article that applies the project-based learning method. This study focuses on implementing the media used by BIPA students in SES grade 6 SD (Year7) to introduce Indonesian tourism through the Canva online software. This research data are the results or assignments of BIPA students in grade 6 SD (Year 7) with the Canva application in the form of tourism infographics or tourism posters. The technique of collecting data is through classroom observation during learning and strengthened by document studies. The main instrument in the research is the researcher by using zoom media. Data was collected by classroom observation in the form of field notes, observations, and the collection of student work.

\section{RESULTS AND DISCUSSION}

\subsection{Characteristics of Year 7 BIPA Students at SES}

BIPA students have different characteristics, it is necessary to have a strategy in teaching. The selection of strategies, methods, and learning media will consider aspects, materials, time, students (number and age), learning steps, and supporting media. Study time determines the strategy that is considered the most appropriate for learning. The strategy is illustrated in the learning steps, which require the media to support learning. The media used in the learning steps are placed in accordance with the BIPA learning objectives. The media used in BIPA learning must help students quickly understand the material with a fun learning atmosphere and not confuse. One strategy that is quite effective and efficient in teaching BIPA to students is to do project-based learning.

Characteristics of Year 7 students at SES are independent in terms of IT and communication skills. The language level at this level is averaged at B1 and B2. Students' communication skills can also be good because most students can argue by choosing the proper diction and applying it in the correct sentence structure. However, there are still students who need assistance regarding language because of one particular thing, for example, students who have just joined the BIPA class. The condition of BIPA students is very diverse, both language and culture. It may cause misinformation, miscommunication in interacting [3].

BIPA learning is currently being followed by many countries, especially in the digital age. This generation is a student with an indicator of birth between 1980 , 
while before birth in 1980 called the immigrant population (digital immigrant). This generation has the skills to process digital information. Classifying learning approaches can focus on students and teachers and the students' technology and IT skills or abilities [4].

SES students have strong basic science and technology skills. This is because students at SES have been equipped with technical knowledge from the Year 1 level (equivalent to Kindergarten). Starting from Year 1, students are given ICT (Information Communication Technology) subjects according to their level, ranging from basic materials (typing, sending emails) to operating various applications (photoshop, Movie Maker, Corel Draw, Prezi, Canva, etc). SES refers to the process-focused Cambridge curriculum. So, BIPA students at SES are used to using online pages and applications that support learning. Students quickly adapt to the online learning process through the zoom channel, which is routinely carried out according to the usual schedule before the pandemic.

Furthermore, the study of language, which is a source of culture and language skills, is one of the cultural practices. Language learning, especially BIPA, as much as possible, can integrate cultural messages implicit in the speaking community according to the context and function to meet learners' needs. Therefore, BIPA learning integrates cultural aspects with language skills, both directly and indirectly, so that students are able to know, experience, and animate Indonesian culture through BIPA learning, Duranti in [5].

\subsection{Tourism and Cultural Insights for BIPA Students}

The natural beauty and charm of Indonesian culture have recently become the world's spotlight. The island of Bali is popular today, but other islands are also starting to be known on the world stage. Not a few foreign nationals are interested in learning Indonesian because of Indonesia's natural and cultural wealth. Foreigners who study Indonesian are not only meant to travel and get to know the culture. Most of those who learn Indonesian have a motivation to study or work in Indonesia. However, the students 'tendency to learn Indonesian at SPK is dominated by the background of their parents who work in Indonesia. Inevitably, students learn Indonesian because the curriculum requires Indonesian language subjects for both Indonesian citizens and foreigners.

Students at SES are always given cultural insight through teaching materials delivered during the learning process. In addition to BIPA learning, culture and local wisdom are also given in other subjects such as music: by introducing angklung, learning to draw Indonesian tours (Bromo, Merapi), making wayang, After school activity is by cooking traditional Indonesian food, traditional games, watching fairy tales, etc.

Activities to introduce tourism and Indonesian culture: demonstration learning; before the pandemic, students can be invited to make field visits (educational tours), so they can get to know Indonesian culture firsthand. Activities that SES has carried out for field studies are visiting Surabaya batik center to find out various kinds of batik motifs and how they are made, visiting organic business products (home industries) in the community, visiting historical tourist attractions, such as Submarine Museum and Hero Monument. Students are also involved in various extracurricular activities that indirectly hone students' communication skills. Social activities are also inseparable from students at SES.

The use of the right BIPA learning method can maximize and facilitate learning. Learners can more easily understand the language being taught, namely Indonesian quickly. Learning carried out in SES is fun learning since the main goal is to enjoy the learning process so that students will not feel bored with getting monotonous learning material. With project-based learning, learners use the language they are learning directly to create fun projects. With these activities, BIPA students easily absorb the material being taught.

\subsection{Student Creativity in Expressing Ideas into Infographics/Canva Media}

Canva is a graphic design medium to facilitate users to be able to design creatively and boldly accessible. The designs that can be designed are posters, brochures, infographics, and presentations. Canva can be accessed using a smartphone or computer. This medium is very in tune with learners in helping to make designs practical and attractive.

Canva is one of the learning media that can be used in online learning as it is today. Due to the limited time to meet face to face and the suitable media, teachers must be really creative in providing learning materials and assessments to students. This media is better known to be used by students studying information technology or computer science. However, currently Canva is also used as a medium for learning Indonesian, such as the BIPA learning conducted at the Surabaya European School for 6th-grade elementary school students (Year 7).

There are several design features in Canva, such as text, filters, colour palette, transparency, and branding. Canva can be used for various Indonesian language learning projects, such as making advertisements, posters, greeting cards, and so on. Canva, with its many features, is not too difficult for young learners to learn. The features are extremely simple, but if you use your creativity, the results will be extraordinary. Plus, Canva 
makes it easy for teachers to help with grammar or spelling mistakes with the file-sharing feature. In this file-sharing, students can also work simultaneously (in groups) by complementing each other.

In the text feature, Canva offers a variety of attractive text templates so that users have beautiful typography and eye-catching. In this feature, Canva users can also adjust the colour of the graphic text with the colour palette according to their wishes and creativity. This can develop students' potential in being creative. With this text feature, BIPA students enjoy the language learning process. They are looking for information about tourism in Indonesia in the form of destinations, food, culture, and so on. By looking for information, students learn to understand Indonesian texts. By citing info to Canva, students learn to write sentences, find important information, as well as Indonesian grammar.

BIPA learning cannot be separated from four language skills: listening, speaking, reading, and writing. In BIPA learning, the teacher does not only provide one language skill since all skills are continuous with each other. When the teacher teaches Indonesian as a foreign language or second language (B2), all language skills are needed, although some skills are focused on the learning objectives.

BIPA learning can be developed systematically and professionally by considering aspects of teaching management, including materials and media [6]. A child can apply the language skills they have had since childhood at the same time, such as listening and speaking while reading and writing. Since childhood, a child acquires oral language skills (listening and speaking) through learning. If a child continues to be trained to write, he must also be trained to read because it is closely related to each other [7]. Children will read the results of their writing activities. Vice versa, they will also write the results of the reading. So, teachers must link the four language skills in language learning, not to be separated, SE Fox \& VG Allen in [8].

Based on the explanation above, BIPA learning should use four language skills in giving assignments to students. Assessments that can be done using Canva media include all basic language skills: listening, reading, writing, and speaking. In line with this, the Canva media given to students at SES is used to hone these four skills. Teachers can practice listening and reading by looking for information about tourism in Indonesia from various internet references and YouTube channels. After getting the information, students make posters with their own creativity. The poster describes tourist attractions in certain areas, typical food, and local culture. Do not forget that students are also asked to give the poster's title as beautiful as possible. It sharpens writing skills by applying grammar that students already understand. After becoming a poster, students can present the results of their posters in front of their classmates so that students practice speaking skills by way of presentation.

BIPA learning for academic purposes is carried out by providing opportunities to communicate to students both verbally and in writing [9]. Many positive sides are obtained through IT-based learning, especially the use of Canva media for Indonesian language expression through tourism infographics. First, students will feel happy since their creativity can be expressed through the media used. Second, the use of information technology is in line with the competencies possessed by students so that they can be more optimal in achieving learning objectives. Third, the combination of Indonesian language competence, IT, and student creativity becomes an inseparable unit so that the infographics presentation can be assessed from various aspects, such as grammar, graphic design, and mastery of language skills.

\section{CONCLUSION}

BIPA learning at the Surabaya European School runs very dynamically. Academic adaptation in a pandemic situation is carried out in an interactive manner by actively involving students in each learning process. Exploration of knowledge of Indonesian culture and tourism can be applied by students by using Canva media. In the process, students search for tourism and cultural information through a reading process from various sources, then applied to Canva media. Canva media is considered to provide an opportunity for students to express their ideas through the presentation of graphic info. The complexity of infographics, substance, and student creativity make BIPA learning more varied and fun.

\section{REFERENCES}

[1] I. Widia, "Alternatif model alat evaluasi kemahiran menyimak Bahasa Indonesia bagi penutur asing berlandaskan alat evaluasi bahasa asing," Jurnal Bahasa Indonesia bagi Penutur Asing (JBIPA), vol. 3, no. 1, pp. 32-41, 2021.

[2] M. Murtianis, A. Andayani, and M. Rohmadi, “Text book as a Java culture recognition media in Indonesıan learning for foreign speaker (BIPA) in Sebelas Maret University," International Journal of Educational Research Review, vol. 4, no. 3, pp. 427-434, 2019.

[3] A. Anindita. and N. Woelandari, "Praktik komunikasi antarbudaya pada mahasiswa ekspatriat dalam program Bahasa Indonesia untuk penutur asing (BIPA)," Jurnal Pustaka Komunikasi, vol. 3, no. 1, pp. 24-36, 2020. 
[4] R. E. Meyer and T. W. Utomo, Multimedia Learning: Prinsip-Prinsip dan Aplikasi Terjemahan. Yogyakarta: Pustaka Pelajar, 2009.

[5] A. M. N. Setiawan, A. Andayani, and K. Saddhono, "Penggunaan media pembelajaran menulis bagi mahasiswa BIPA untuk memahami budaya lokal," Komposisi: Jurnal Pendidikan Bahasa, Sastra, dan Seni, vol. 18, no. 1, pp. 66-79, 2017.

[6] S. Tanwin and R. Rosliani, "The development of Indonesian language teaching materials for beginner level of foreign speakers with local content," Budapest International Research and Critics in Linguistics and Education (BirLEJournal), vol. 3, no. 3, pp. 1600-1613, 2020.

[7] D. Defina, "Penilaian mahasiswa BIPA terhadap pembelajaran tatap muka dan online," Jurnal Bahasa Indonesia bagi Penutur Asing (JBIPA), vol. 3, no. 1, pp. 12-23, 2021.

[8] D. Defina, "Bentuk tugas dan evaluasi empat keterampilan berbahasa pada Bahasa Indonesia untuk penutur asing (BIPA)," Dialektika: Jurnal Bahasa, Sastra, dan Pendidikan Bahasa dan Sastra Indonesia, vol. 4, no. 2, pp. 259-283, 2017.

[9] L. W. Setyaningrum, A. Andayani, and K. Saddhono, "Pembelajaran afiks Bahasa Indonesia bagi penutur asing (BIPA) di Provinsi Daerah Istimewa Yogyakarta," Jurnal Imajeri: Jurnal Pendidikan Bahasa dan Sastra Indonesia, vol. 1, no. 1, pp. 49-61, 2018. 